\title{
Comparison of external udder measurements of the sheep breeds Improved Valachian, Tsigai, Lacaune and their crosses
}

\author{
Pavol Makovick $\dot{y}^{1 *}$, Melinda Nagy ${ }^{1}$, and Peter Makovick $\dot{y}^{2}$
}

\begin{abstract}
Morphological udder traits have recently become of greater interest from farmers to researchers. In dairy ewes, the udder is very important due to its physiological and conformational characteristics. External udder traits were measured in ewes (Ovis aries L.) of nine genotypes (355 ewes) created of the basis of Improved Valachian (IV), Tsigai (T), and Lacaune (LC) breeds (six traits; 1185 data for each trait) during the milking period 2002-2008. Udder measurements were assessed for: udder length (UL), udder width (UW), rear udder depth (RUD), cistern depth (CDE), teat length (TL), and teat angle (TA). Data were processed by restricted maximum likelihood (REML) methodology using a MIXED procedure from the SAS statistical package. All studied parameters were influenced by the genotype $(\mathrm{P}<0.001)$, many of them also by the effect of parity and lactation stage. The exactly detected UL, UW and RUD during the lactation and with the age of ewes expand gradually $(\mathrm{P}<0.001)$. Teat length was greater in older ewes (expanding, with the parity). Indicator TA during lactation worsened. Crosses with 25 to $75 \%$ share of genetic dairy breeds (in particular with LC, to a lesser extent 'East Friesian' EF) were in most cases larger than the udder cisterns of purebred ewes T and IV. Purebred LC had the largest udders, with the largest cisterns. In conclusion, crosses with specialized dairy breeds have more suitable udders for machine milking than purebred default breeds (T, IV, LC) and are suitable for machine milking.
\end{abstract}

Key words: Dairy, ewes, lactation, mammary morphology, Ovis aries, teat, udder measurements.

\section{INTRODUCTION}

The anatomy and morphology of the sheep (Ovis aries L.) udder is well known for many years due to many scientific papers (Sagi and Morag, 1974; Labussière et al., 1981; Labussière, 1988; Tenev and Rusev, 1989; Ruberte et al., 1994; Pulina and Nudda, 1996; Pulina et al., 1996; Tatarczuch et al., 1997; Carretero et al., 1999; Pulina et al., 2009). The study of the anatomical structure of mammary gland is useful for improving milk yield (Salaris et al., 2007; Casu et al., 2008; Emediato et al., 2008; Rovai et al., 2008; Kominakis et al., 2009; Blaščáková and Poráčová, 2009; Sadeghi et al., 2013) and good milking ability (Labussière, 1988; Bruckmaier et al., 1997; Marnet and McKusick, 2001; Bencini et al., 2003; Džidić et al., 2004; Marie-Etancelin et al., 2006; Castillo et al., 2008a; 2008b; Makovický et al., 2012; 2013). Animals that store a large proportion of milk in the gland cistern produce more milk, and are more able to

${ }^{1}$ J. Selye University, Pedagogical Faculty, Department of Biology, Bratislavská 3322945 01, Komárno, Slovak Republic. *Corresponding author (makovicky.pavol@gmail.com).

${ }^{2}$ Czech University of Life Sciences, Faculty of Agrobiology, Food and Natural Resources, Department of Veterinary Sciences, Kamýcká 129 (street) 16521 Prague 6 - Suchdol, Prague, Czech Republic.

Received: 18 May 2013.

Accepted: 3 September 2013.

doi: $10.4067 /$ S0718-58392013000400006 tolerate extended milking intervals (Knight and Dewhurst, 1994; Stelwagen et al., 1996; Davis et al., 1998; Ayadi et al., 2003; Salama et al., 2003; 2004; Ayadi et al., 2009; Castillo et al., 2009). There are several factors which may affect udder morphology and, therefore, milking efficiency; these include genotype, number and stage of lactation and milk yield (Fernández et al., 1995; Džidić et al., 2004; Ugarte and Gabiña, 2004; Casu et al., 2008). Mammary morphology is a key factor for optimizing machine-milking ability in ruminants and its inclusion in dairy sheep improvement programs has been widely recommended (Labussière, 1988; De la Fuente et al., 1996; Caja et al., 2000; Rovai et al., 2004). The external udder traits have been researched in various dairy sheep breeds and have been investigated by a number of authors ('Churra': Fernández et al., 1995; 'East Friesian': McKusick et al., 2000; 'Manchega' and 'Lacaune': Rovai et al., 2008; 'Istrian': Džidić et al., 2004; Prpić et al., 2013; 'Bergamasca': Emediato et al., 2008; 'Kermani': Kahtuei et al., 2008; 'Frizarta': Kominakis et al., 2009; 'Improved Valachian' and 'Tsigai': Makovický, 2009; 'Awassi': Iñiguez et al., 2009; 'Sicilo-Sarde': Ayadi et al., 2011; 'Kıvırcık', 'Tahirova' and 'Karacabey': Altinçekiç and Koyuncu, 2011; 'Assaf': Legaz et al., 2011, PérezCabal et al., 2013; 'Lori Bakhtiari' breed ewes: Sadeghi et al., 2013). Udder morphological traits in meat breeds ('Chilota', 'Suffolk Down') and their relationship with milk production were studied by Martínez et al. (2011). 
The objective of this research was to investigate the external udder measurements in purebred 'Improved Valachian' (IV), 'Tsigai' (T), 'Lacaune' (LC) and their crosses with $25 \%, 50 \%$, and $75 \%$ genetic proportion of LC and 'East Friesian' (EF). The analyses of genetic and non-genetic factors that are expected to influence the udder morphology were also done.

\section{MATERIALS AND METHODS}

The experiment was performed during the 7-yr period from 2002 to 2008 in one experimental flock of dairy sheep. Each year the ewes were kept within the same flock and were milked twice a day. Purebred 'Improved Valachian' (IV), purebred 'Tsigai' (T) and purebred 'Lacaune' (LC) ewes, and IV and T crosses with $25 \%$, $50 \%$, and $75 \%$ genetic proportion of specialized dairy breeds (SDB) 'Lacaune' and 'East Friesian' (EF) were included in the experiment $(\mathrm{IV} \times \mathrm{SDB} 25 \%, \mathrm{IV} \times \mathrm{SDB}$ $50 \%, \mathrm{IV} \times \mathrm{SDB} 75 \%$; $\mathrm{T} \times \mathrm{SDB} 25 \%, \mathrm{~T} \times \mathrm{SDB} 50 \%$, $\mathrm{T} \times \mathrm{SDB} 75 \%$ ). In total, we compared the external udder measurements in nine genotypes of ewes (three purebreds and six groups of crossbreds). Most crosses created were based on the breed $\mathrm{T}$ respectively IV were two-breeding crosses with $25 \%, 50 \%$, and $75 \%$ of LC breed's genetic proportion. Three-breeding crosses with $25 \%, 50 \%$ and $75 \%$ of the genetic contribution of both dairy breeds LC and IV represented for the whole period significantly less of the evaluated population (17 ewes, i.e. about $5 \%$ of the population). Ewes included in the experiment represented all nine genotypes in each of the reviewed years on the first, second, third, and higher lactation. Most measurements were made in May and July. Control measurements of ewes' udders size were always conducted after the evening milking, and then after the morning milking. During dairy period at least two but in some years up to four control measurements of milk were performed. Some ewes were included in the experiment in $2 \mathrm{yr}$ or even more years which means that in case of some ewes up to eight control measurements of milk were conducted. For the whole period, we surveyed the exact udder size of 355 ewes. Per each ewe the average from 2.84 to 3.47 of measurements were carried out depending on the monitored indicator. Specific numbers of observations in monitored indicators depending on the genotype, parity and lactation stage are shown in Tables 1 and 2. The methodology used for measuring udder traits (Figure 1) was that described by Milerski et al. (2006). External udder measurements of six traits were made by at least two technicians using ruler, measuring tape, and protractor and they included: udder length (UL), udder width (UW), rear udder depth (RUD), cistern depth (CDE), teat length (TL) and teat angle from the vertical (TA). Statistical analysis was done using the restricted

Table 1. Effect of genotype on traits describing external udder measurements of ewes (LSM $\pm \mathrm{SE})$.

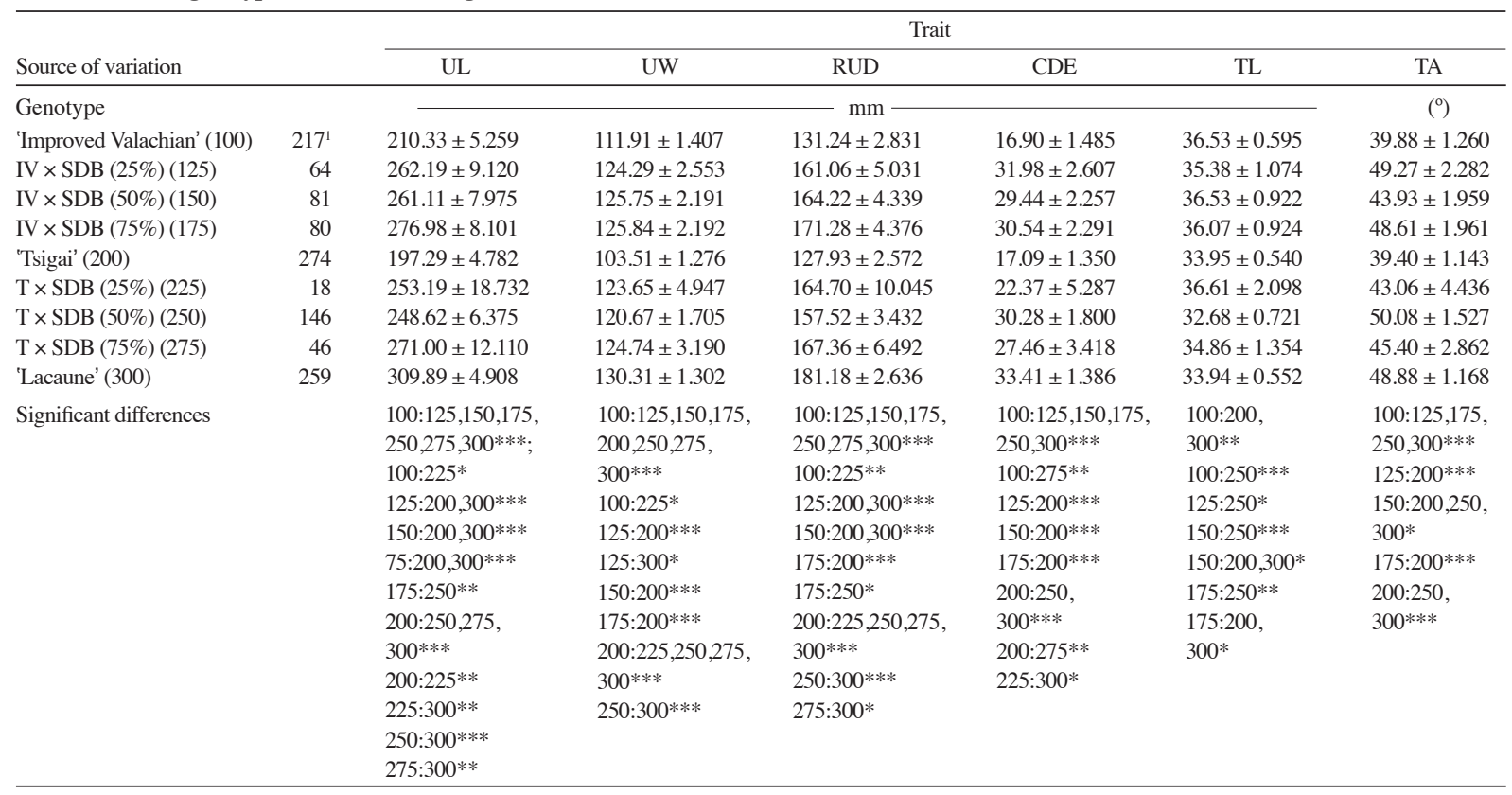

$* * * \mathrm{P}<0.001 ; * * \mathrm{P}<0.01 ; * \mathrm{P}<0.05 ;$ ns: non-significant effect.

UL: udder length; UW: udder width; RUD: rear udder depth; CDE: cistern depth; TL: teat length; TA: teat angle; SDB: specialized dairy breeds; LSM \pm SE: least square means \pm standard error.

(100): 'Improved Valachian' (IV); (125): crossbreds of IV breed with 25\% genetic proportion of specialized dairy breeds Lacaune (LC) and East Friesian (EF); (150): crossbreds of IV breed with $50 \%$ genetic proportion of specialized dairy breeds LC and EF; (175): crossbreds of IV breed with $75 \%$ genetic proportion of specialized dairy breeds LC and EF; (200): 'Tsigai' (T); (225): crossbreds of T breed with 25\% genetic proportion of specialized dairy breeds LC and EF; (250): crossbreds of T breed with $50 \%$ genetic proportion of specialized dairy breeds LC and EF; (275): crossbreds of T breed with $75 \%$ genetic proportion of specialized dairy breeds LC and EF; (300): LC. ${ }^{1}$ Number of measurements. 
Table 2. Effect of parity and stage of lactation on traits describing external udder measurements of ewes $(\mathrm{LSM} \pm \mathrm{SE})$.

\begin{tabular}{|c|c|c|c|c|c|c|c|}
\hline \multirow[b]{2}{*}{ Source of variation } & \multicolumn{7}{|c|}{ Trait } \\
\hline & & UL & UW & RUD & $\mathrm{CDE}$ & $\mathrm{TL}$ & TA \\
\hline \multicolumn{8}{|l|}{ Parity } \\
\hline $1^{\text {st }}$ order of lactation & $390^{1}$ & $243.29 \pm 3.600$ & $119.26 \pm 1.012$ & $150.78 \pm 1.966$ & $25.37 \pm 1.019$ & $33.72 \pm 0.423$ & $44.93 \pm 0.902$ \\
\hline $2^{\text {nd }}$ order of lactation & 355 & $253.79 \pm 3.592$ & $120.62 \pm 1.049$ & $156.97 \pm 1.984$ & $25.76 \pm 1.019$ & $35.42 \pm 0.435$ & $45.01 \pm 0.931$ \\
\hline $3^{\text {rd }}$ and further order of lactation & 440 & $266.45 \pm 3.795$ & $123.67 \pm 1.083$ & $167.75 \pm 2.085$ & $28.69 \pm 1.076$ & $36.37 \pm 0.452$ & $46.24 \pm 0.965$ \\
\hline Significant differences & & $1: 2,3 * * * ; 2: 3 * * *$ & $1: 3 * * * ; 2: 3 * *$ & $1: 2,3 * * * ; 2: 3 * * *$ & $1: 3 * * * ; 2: 3 * * *$ & $1: 2,3 * * * ; 2: 3 *$ & ns \\
\hline \multicolumn{8}{|l|}{ Lactation stage } \\
\hline $40^{\text {th }}-99^{\text {th }}$ day $(1)$ & 258 & $255.52 \pm 5.700$ & $119.16 \pm 2.038$ & $154.54 \pm 3.371$ & $27.47 \pm 1.639$ & $35.73 \pm 0.811$ & $47.09 \pm 1.778$ \\
\hline $100^{\text {th }}-129^{\text {th }}$ day (2) & 350 & $246.54 \pm 3.752$ & $119.49 \pm 1.150$ & $156.50 \pm 2.099$ & $25.77 \pm 1.067$ & $35.75 \pm 0.471$ & $44.59 \pm 1.015$ \\
\hline $130^{\text {th }}-159^{\text {th }}$ day (3) & 331 & $251.50 \pm 3.897$ & $121.54 \pm 1.219$ & $159.99 \pm 2.196$ & $26.50 \pm 1.101$ & $35.20 \pm 0.497$ & $46.31 \pm 1.074$ \\
\hline $160 t^{\text {th }}-210^{\text {th }}$ day (4) & 246 & $264.48 \pm 5.525$ & $124.55 \pm 1.968$ & $162.97 \pm 3.261$ & $26.69 \pm 1.588$ & $34.00 \pm 0.784$ & $43.57 \pm 1.717$ \\
\hline Significant differences & & $1: 2^{*} ; 2: 4^{* *} ; 3: 4^{* * *}$ & $2: 4^{*} ; 3: 4^{*}$ & ns & ns & $3: 4^{*}$ & $3: 4 *$ \\
\hline
\end{tabular}

***P $<0.001 ; * * \mathrm{P}<0.01 ; * \mathrm{P}<0.05 ;$ ns: non-significant effect; LSM \pm SE: least square means \pm standard error; UL: udder length; UW: udder width; RUD: rear udder depth; CDE: cistern depth; TL: teat length; TA: teat angle.

${ }^{1}$ Number of measurements.
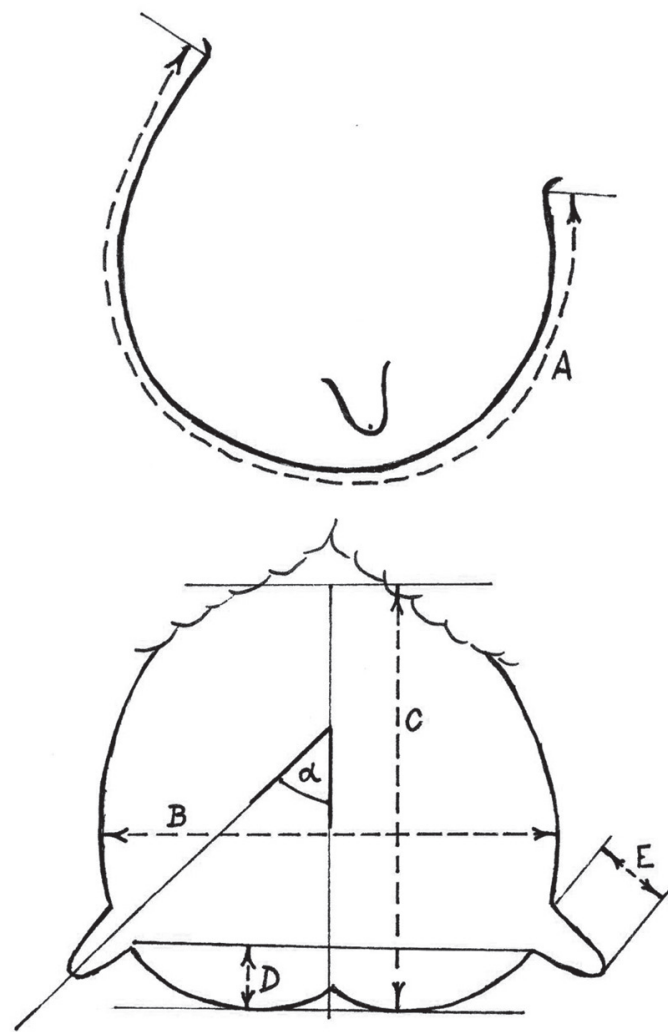

A: udder length (UL); B: udder width (UW); C: rear udder depth (RUD); D: cistern depth (CD); E: teat length (TL); $\alpha$ : teat angle from the vertical (TA).

Figure 1. Morphological parameters measured on udder and teats.

maximum likelihood (REML) methodology (MIXED) procedure as implemented in SAS/STAT v.9.2, (SAS Institute, 2002-2008).

The following statistical model with fixed and random effects was applied:

$$
\begin{aligned}
\mathrm{y}_{\mathrm{ijklm}} & =\mu+\mathrm{Y}_{\mathrm{i}}+\mathrm{LS}_{\mathrm{j}}+\mathrm{GEN}_{\mathrm{k}}+\mathrm{P}_{\mathrm{l}}+a n_{m}+\mathrm{a} * \mathrm{DIM}_{\mathrm{ijklm}} \\
& +e_{i j k l m}
\end{aligned}
$$

where: $y_{i j k l m}$ is dependent variables studied, such as (UL, UW, RUD, CDE, TL, TA), $Y_{i}$ is year (fixed effect with five to seven levels; depending on the analyzed indicator $2002-$ 2008), $L S_{j}$ is lactation stage (fixed effect with four levels), from $40^{\text {th }}$ to $99^{\text {th }}$ lactation day, from $100^{\text {th }}$ to $129^{\text {th }}$ lactation day, from $130^{\text {th }}$ to $159^{\text {th }}$ lactation day and from $160^{\text {th }}$ to $210^{\text {th }}$ lactation day, $G E N_{k}$ is genotype (breed group; fixed effect with nine levels; see above for characterization), $P_{1}$ is parity (fixed effect with three levels; - first, second, third and further parity), $a n_{m}$ is animal (random effect), $D I M_{i j k l m}$ is days in milk (covariate; 40 to $210 \mathrm{~d}$ in milk), $e_{i j k l m}$ is random error. The differences were significant at $\mathrm{P}$ $<0.05, \mathrm{P}<0.01$, and $\mathrm{P}<0.001$.

\section{RESULTS AND DISCUSSION}

The basic statistical characteristics of the variation of selected parameters characterizing the external udder measurements of ewes for IV, T, LC and their crosses with genetic proportion of LC and EF-25\%, 50\%, and $75 \%$ are shown in Table 3. While measuring the exact udder sizes of ewes (UL, UW, RUD, CDE, TL, and TA) using ruler, measuring tape and protractor, we realized 1185 measurements, and we found extraordinary great variability of values. The lowest average value for the exact udder sizes of ewes was found in the indicator cistern depth on level $(25.33 \mathrm{~mm})$, and the highest average value was found in the indicator udder length $(248.72 \mathrm{~mm})$. The average udder length is characterized by a relatively large margin, where the minimum value for this parameter was detected at $110 \mathrm{~mm}$ and a maximum value at 570 $\mathrm{mm}$. Coefficients of variation were medium high for all indicators, with the exception of CDE indicator, where

Table 3. Basic statistical characteristics of the variation of selected parameters characterizing the external udder measurements of ewes.

\begin{tabular}{lrrrrrc}
\hline Traits & $\mathrm{n}^{1}$ & Mean & SD & CV & Minimum & Maximum \\
\hline Udder length, mm & 1185 & 248.72 & 64.33 & 25.86 & 110 & 570 \\
Udder width, mm & 1185 & 119.04 & 18.46 & 15.51 & 70 & 190 \\
Rear udder depth, mm & 1185 & 154.11 & 34.64 & 22.48 & 10 & 310 \\
Cistern depth, mm & 1185 & 25.33 & 15.55 & 61.39 & 0 & 85 \\
Teat length, mm & 1185 & 34.77 & 6.05 & 17.40 & 20 & 70 \\
Teat angle & 1185 & 44.45 & 13.40 & 30.15 & 0 & 90 \\
\hline
\end{tabular}

${ }^{1}$ Number of sets of measurements.

SD: standard deviation; CV: coefficient of variability. 
we found that the coefficient of variation was as high as $61.39 \%$. This means that some cisterns of the monitored ewes were negligible $(0 \mathrm{~mm})$, while the cisterns in some ewes were very large $(85 \mathrm{~mm})$.

Our results show (Table 4) that genotype had a significant effect on all the studied parameters of the exact udder sizes of experimental ewes $(\mathrm{P}<0.001)$. Significant effect of genotype on exact udder sizes of 'Churra' ewes also found Fernández et al. (1995) and De la Fuente et al. (1996).

As shown in Table 1, the highest average udder length $(309.89 \pm 4.908 \mathrm{~mm})$ was found in purebred LC ewes. The smallest average udder length $(197.29 \pm 4.782 \mathrm{~mm})$ was found in purebred $\mathrm{T}$ ewes. Lower average values in comparison with our results were indicated by Rovai et al. (2008) for purebred 'Manchega' ewes (12 cm) and LC $(11.5 \mathrm{~cm})$, respectively Kahtuei et al. (2008) in 'Kermani' (11.97 \pm 0.142), Iñiguez et al. (2009) in 'Awassi' (10.7 $\mathrm{cm}$ ), and McKusick et al. (2000) for EF ewes (19.7 \pm $1.8 \mathrm{~cm})$. On the contrary, higher values in comparison with our results were found by Altinçekiç and Koyuncu (2011), who report the average of UL between (21.32 \pm 2.64 to $23.01 \pm 2.69 \mathrm{~cm}$ ) in 'Kivircık', 'Tahirova' and 'Karacabey'.

Purebred LC ewe, as expected, also reached the largest average UW $(130.31 \pm 1.302 \mathrm{~mm})$. Minimum average UW was found in purebred T ewes $(103.51 \pm 1.276 \mathrm{~mm})$. Similar results were also report by Fernández et al. (1995) in 'Churra' $(12.18 \mathrm{~cm})$, respectively Altinçekiç and Koyuncu (2011) found the average of UW ranging from $(12.28 \pm 0.93$ to $13.17 \pm 1.24 \mathrm{~cm})$ in 'K1vircik', 'Tahirova' and 'Karacabey'. Higher values compared with our results were observed by Emediato et al. (2008) in 'Bergamasca' (from 16.86 to $17.70 \mathrm{~cm}$ ), Iñiguez et al. (2009) in 'Awassi' $(13.5 \mathrm{~cm})$, Kominakis et al. (2009) in 'Frizarta' (14.47 \pm $0.11 \mathrm{~cm}$ ) and Sadeghi et al. (2013) in 'Lori Bakhtiari' ewes (from 15.1 to $18.4 \mathrm{~cm}$ ). Lower average values in comparison with our results were indicated by Kahtuei et al. (2008) in 'Kermani' (6.02 $\pm 0.062 \mathrm{~cm})$.

The next monitored indicator was RUD. The comparison between genotype groups shows that the greatest RUD $(181.18 \pm 2.636 \mathrm{~mm})$ characterizes purebred LC ewes. The smallest average RUD we found, as expected, for purebred $\mathrm{T}$ ewes $(127.93 \pm 2.572 \mathrm{~mm})$. Lower results for RUD indicator were published by Fernández et al. (1995) in 'Churra' $(9.30 \mathrm{~cm})$, respectively by Kahtuei et al. (2008) in 'Kermani' $(10.53 \pm 0.160 \mathrm{~cm})$ and Ayadi et al. (2011) in 'Sicilo-Sarde' (5.04 $\pm 0.14 \mathrm{~cm})$. Altinçekiç and Koyuncu (2011) referred to average udder depth ranging from $(7.34 \pm 0.93$ to $7.67 \pm 1.41 \mathrm{~cm})$ in 'Kivircik', 'Tahirova' and 'Karacabey' and Emediato et al. (2008) in 'Bergamasca' ewes (from 17.34 to 19.14 $\mathrm{cm})$. Higher results than our own were found by Rovai et al. (2008) in 'Manchega' $(19.6 \mathrm{~cm})$ and LC (22.5 cm).

As for the cistern depth (CDE) indicator, our results show that the largest CDE characterized purebred LC ewes $(33.41 \pm 1.386 \mathrm{~mm})$. In purebred $\mathrm{T}$ ewes we found an average cistern depth $(17.09 \pm 1.350 \mathrm{~mm})$, while the lowest average cistern depth was measured in purebred IV ewes $(16.90 \pm 1.485 \mathrm{~mm})$. Lower values compared with our results were referred to by Fernández et al. (1995) in 'Churra' $(1.48 \mathrm{~cm})$. Values in accordance with our results were published by Iñiguez et al. (2009) in 'Awassi' (3.4 $\mathrm{cm})$, respectively McKusick et al. (2000) in EF ewes (2.8 $\pm 1.2 \mathrm{~cm}$ ). Rovai et al. (2008) found in 'Manchega' 15.6 $\mathrm{cm}$ and in the LC breed $27.1 \mathrm{~cm}$. Kominakis et al. (2009) found $3.57 \pm 0.13 \mathrm{~cm}$ average cistern depth in 'Frizarta' and Sadeghi et al. (2013) in the 'Lori Bakhtiari'ewes (from 1.63 to $3.23 \mathrm{~cm}$ ).

A greater teat length was observed $36.61 \pm 2.098 \mathrm{~mm}$ in crosses $\mathrm{T} \times \mathrm{SDB}(25 \% \mathrm{SDB})$ compared to purebreds LC ewes $(33.94 \pm 0.552 \mathrm{~mm})$. The lowest average teat length $(32.68 \pm 0.721 \mathrm{~mm})$ was found in crosses $\mathrm{T} \times$ SDB (50\% SDB). Lower average results of teat length compared with our results were found by Fernández et al. (1995) in 'Churra' (3.83 cm), Emediato et al. (2008) in the 'Bergamasca' ewes (2.86 to $2.91 \mathrm{~cm})$, Kahtuei et al. (2008) in 'Kermani' $(2.64 \pm 0.620 \mathrm{~cm})$, respectively Ayadi et al. (2011) at 'Sicilo-Sarde' (18.5 $\pm 4.9 \mathrm{~mm})$ and Altinçekiç and Koyuncu (2011) in 'Kıvırcık', 'Tahirova' and 'Karacabey' ranged from (2.68 \pm 0.47 to $2.88 \pm 0.38$ $\mathrm{cm})$. Values in accordance with ours were found by Rovai et al. (2008) in 'Manchega' (42.7 mm) and LC breed at $(32.7 \mathrm{~mm})$. Iñiguez et al. (2009) found in 'Awassi' average teat length $3.4 \mathrm{~cm}$, Kominakis et al. (2009) for 'Frizarta' $3.42 \pm 0.06 \mathrm{~cm}$ and Sadeghi et al. (2013) in the 'Lori Bakhtiari' ewes (from 2.32 to $3.25 \mathrm{~cm}$ ).

Regarding teat angle, the highest average values for teat angle were found among all genotype groups at crosses $\mathrm{T}$ $\times \mathrm{SDB}(50 \% \mathrm{SDB})$ at $50.08 \pm 1.527$; the lowest average teat angle we found in purebred Tsigai ewes (39.40 \pm $\left.1.143^{\circ}\right)$. Similar average teat angles were reported in

Table 4. Covariance analysis of traits describing external udder measurements of ewes.

\begin{tabular}{|c|c|c|c|c|c|c|c|c|c|c|c|c|c|}
\hline \multirow[b]{3}{*}{ Source of variation } & \multirow[b]{3}{*}{ df } & \multicolumn{12}{|c|}{ Trait } \\
\hline & & \multicolumn{2}{|c|}{ UL } & \multicolumn{2}{|c|}{ UW } & \multicolumn{2}{|c|}{ RUD } & \multicolumn{2}{|c|}{$\mathrm{CDE}$} & \multicolumn{2}{|c|}{$\mathrm{TL}$} & \multicolumn{2}{|c|}{ TA } \\
\hline & & F value & $\mathrm{P}>\mathrm{F}$ & F value & $\mathrm{P}>\mathrm{F}$ & F value & $\mathrm{P}>\mathrm{F}$ & F value & $\mathrm{P}>\mathrm{F}$ & F value & $\mathrm{P}>\mathrm{F}$ & F value & $\mathrm{P}>\mathrm{F}$ \\
\hline Year & 5 & 4.62 & 0.0004 & 26.58 & $<0.0001$ & 17.62 & $<0.0001$ & 18.99 & $<0.0001$ & 9.60 & $<0.0001$ & 1.81 & 0.1081 \\
\hline Lactation stage & 3 & 14.01 & $<0.0001$ & 2.27 & 0.0795 & 1.00 & 0.3903 & 1.82 & 0.1414 & 2.34 & 0.0719 & 4.38 & 0.0045 \\
\hline Genotype & 8 & 42.65 & $<0.0001$ & 34.14 & $<0.0001$ & 37.37 & $<0.0001$ & 15.62 & $<0.0001$ & 3.60 & 0.0004 & 8.70 & $<0.0001$ \\
\hline Parity & 2 & 22.75 & $<0.0001$ & 8.26 & 0.0003 & 38.03 & $<0.0001$ & 7.52 & 0.0006 & 17.79 & $<0.0001$ & 1.17 & 0.3105 \\
\hline Days in milk & 1 & 13.19 & 0.0003 & 27.69 & $<0.0001$ & 14.09 & 0.0002 & 1.41 & 0.2356 & 0.17 & 0.6830 & 4.29 & 0.0387 \\
\hline
\end{tabular}

UL: Udder length; UW: udder width; RUD: rear udder depth; CDE: cistern depth; TL: teat length; TA: teat angle. 
'Churra' ewes $\left(50.39^{\circ}\right)$ by Fernández et al. (1995) and Džidić et al. (2004) in 'Istrian' ewes (from $44 \pm 2^{\circ}$ to 49 $\pm 4^{\circ}$ ), Ayadi et al. (2011) in 'Sicilo-Sarde' $\left(45.2 \pm 10.0^{\circ}\right)$, Kominakis et al. (2009) in the 'Frizarta' ewes (51.9 \pm $\left.1.4^{\circ}\right)$, respectively. Lower average results compared with ours were measured by Altinçekiç and Koyuncu (2011) in 'Kıvırcık', 'Tahirova' and 'Karacabey', where average teat angle ranged from $\left(30.72 \pm 1.71\right.$ to $\left.31.98 \pm 2.14^{\circ}\right)$.

Table 2 shows that the factor order of lactation had a statistically significant $(\mathrm{P}<0.001)$ effect on the UL, UW and RUD, on CDE and TL. We found that the largest udders with the largest cisterns had sheep on the third lactation. Older ewes in most cases have significantly greater TL than the first lactation ewes, but during the stage of lactation it became smaller. Similar results were published by Fernández et al. (1995) and De la Fuente et al. (1996) also, and they note that age, respectively order of lactation increases mammary glands of ewes, but decreases TA.

\section{CONCLUSION}

In comparing the observed genotypes of sheep, we found relatively large differences. Our results show that crosses have more suitable udders for machine milking than default breeds ('Tsigai' and, 'Improved Valachian'). The outcome of our research also indicates that specialized dairy breeds ('Lacaune' and, 'East Friesian') are suitable for machine milking, and we can expect better milkability than in the purebred, 'Lacaune' ewes.

\section{ACKNOWLEDGEMENT}

This study was written during realization of the project KEGA 016PU-4/2012 "Animal and Human Physiology, Adaptation and Environment".

\section{LITERATURE CITED}

Altinçekiç, S.Ö., and M. Koyuncu. 2011. Relationship between udder measurements and the linear scores for udder morphology traits in Kıvırcık, Tahirova and Karacabey Merino ewes. Journal of the Faculty of Veterinary Medicine Kafkas University 17:7176.

Ayadi, M., G. Caja, X. Such, and C.H. Knight. 2003. Effect of omitting one milking weekly on lactational performances and morphological udder changes in dairy cows. Journal of Dairy Science 86:2352-2358.

Ayadi, M., N. Ezzehizi, M. Zouari, T. Najar, M. Ben M Rad, X. Such, et al. 2009. Mammary morphology of Sicilo-Sarde dairy sheep raised Tunisia. p. 470. In $60^{\text {th }}$ Annual Meeting of the European Federation of Animal Science (EAAP), Barcelona, Spain. 24-27 August. EAAP, Rome, Italy.

Ayadi, M., X. Such, N. Ezzehizi, M. Zouari, T. Najar, M. Ben M Rad, et al. 2011. Relationship between mammary morphology traits and milk yield of Sicilo-Sarde dairy sheep in Tunisia. Small Ruminant Research 96:41-45.

Bencini, R., T.W. Knight, and P.E. Hartmann. 2003. Secretion of milk and milk components in sheep. Australian Journal of Experimental Agriculture 43:529-534.
Blaščáková, M., and J. Poráčová. 2009. Monitoring mliečnej úžitkovosti v ekologických a konvenčných podmienkach chovu malých prežúvavcov. p. 30-34. Ochrana zvir̃at a welfare 2009. 22-23 September. Veterinární a Farmaceutická Univerzita Brno, Czech Republic.

Bruckmaier, R.M., G. Paul, H. Mayer, and D. Schams. 1997. Machine milking of Ostfriesian and Lacaune dairy sheep: udder anatomy, milk ejection and milking characteristics. Journal of Dairy Research 64:163-172.

Caja, G., X. Such, and M. Rovai. 2000. Udder morphology and machine milking ability in dairy sheep. p. 25-48. Proceedings of the $6^{\text {th }}$ Great Lakes Dairy Sheep Symposium, Guelph, Ontario. 2-4 November 2000. Ontario Dairy Sheep Association, Ontario, Canada.

Carretero, A., J. Ruberte, G. Caja, F.J. Pérez-Aparicio, X. Such, S. Peris, et al. 1999. Study on the structure and the development of the canalicular system of the mammary gland during lactation in Manchega and Lacaune dairy sheep. p. 35-40. In Barillet, F., and N.P. Zervas (eds.) Milking and milk production of dairy sheep and goats. European Federation of Animal Science (EAAP) Publication nr 95, Wageningen Press, Wageningen, The Netherlands.

Castillo, V., X. Such, G. Caja, R. Casals, E. Albanell, and A.A.K. Salama. 2008a. Effect of milking interval on milk secretion and mammary tight junction permeability in dairy ewes. Journal of Dairy Science 91:2610-2619.

Castillo, V., X. Such, G. Caja, R. Casals, A.A.K. Salama, and E. Albanell. 2009. Long- and short-term effects of omitting two weekend milkings on the lactational performance and mammary tight junction permeability of dairy ewes. Journal of Dairy Science 92:3684-3695.

Castillo, V., X. Such, G. Caja, A.A.K. Salama, E. Albanell, and R. Casals. 2008b. Changes in alveolar and cisternal compartments induced by milking interval in the udder of dairy ewes. Journal of Dairy Science 91:3403-3411.

Casu, S., C. Marie-Etancelin, C. Robert-Granié, F. Barillet, and A. Carta. 2008. Evolution during the productive life and individual variability of milk emission at machine milking in Sardinian $x$ Lacaune back-cross ewes. Small Ruminant Research 75:7-16.

Davis, S.R., V.C. Farr, P.J.A. Copeman, V.R. Carruthers, C.H. Knight, and K. Stelwagen. 1998. Partitioning of milk accumulation between cisternal and alveolar compartments of the bovine udder: Relationship to production loss during once daily milking. Journal of Dairy Research 65:1-8.

De la Fuente, L.F., G. Fernández, and F. San Primitivo. 1996. A linear evaluation system for udder traits of dairy ewes. Livestock Production Science 45:171-178.

Džidić, A., M. Kaps, and R.M. Bruckmaier. 2004. Machine milking of Istrian dairy crossbreed ewes: udder morphology and milking characteristics. Small Ruminant Research 55:183-189.

Emediato, R.M.S., E.R. Siqueira, M.M. Stradiotto, S.A. Maestá, and S. Fernandes. 2008. Relationship between udder measurements and milk yield in Bergamasca ewes in Brazil. Small Ruminant Research 75:232-235.

Fernández, G., P. Álvarez, F. San Primitivo, and L.F. De la Fuente. 1995. Factors affecting variation of udder traits of dairy ewes. Journal of Dairy Science 78:842-849.

Iñiguez, L., M. Hilali, D.L. Thomas, and G. Jesry. 2009. Udder measurements and milk production in two Awassi sheep genotypes and their crosses. Journal of Dairy Science 92:4613-4620.

Kahtuei, R.M.,A.Z. Shahneh, and M.M. Sharebabak. 2008. Lactation performance and suckling lamb growth of Kermani fat-tailed ewe. Journal of Animal and Veterinary Advances 7:1575-1578.

Knight, C.H., and R.J. Dewhurst. 1994. Once daily milking of dairy cows: Relationship between yield loss and cisternal milk storage. Journal of Dairy Research 61:441-449.

Kominakis, A.P., D. Papavasiliou, and E. Rogdakis. 2009. Relationships among udder characteristics, milk yield and, nonyield traits in Frizarta dairy sheep. Small Ruminant Research 84:82-88. 
Labussière, J. 1988. Review of physiological and anatomical factors influencing the milking ability of ewes and the organization of milking. Livestock Production Science 18:253-274.

Labussière, J.,D. Dotchewski, et J.F. Combaut. 1981. Caractéristiques morphologiques de la mamelle des brebis Lacaune. Méthodologie pour l'obtention des données. Relations avec l'aptitude à la traite. Annales de Zootechnie 30:115-136.

Legaz, E., I. Cervantes, M.A. Pérez-Cabal, L.F. De la Fuente, R. Mártinez, F. Goyache, et al. 2011. Multivariate characterisation of morphological traits in Assaf (Assaf.E) sheep. Small Ruminant Research 100:122-130.

Makovický, P. 2009. Morphological and functional udder traits as related to production and quality of ewe's milk. Thesis $\mathrm{PhD}$. Slovak University of Agriculture (UNIAG), Nitra, Slovakia.

Makovický, P., M. Nagy, P. Makovický, and Cs. Szinetár. 2013. Milk quality comparison of the sheep breeds (Improved Valachian, Tsigai, Lacaune) and their crosses. Magyar Allatorvosok Lapja 135:85-90

Makovický, P., M. Nagy, J. Poráčová, V. Sedlák, and M. Blaščáková. 2012. The milkability of sheep and the kinetics of milk ejection. Acta Facultatis Studiorum Humanitatis et Naturae Universitatis Prešoviensis 22:146-153.

Marie-Etancelin, C., E. Manfredi, M.R. Aurel, F. Pailler, J. Arhainx, E. Ricard, et al. 2006. Genetic analysis of milking ability in Lacaune dairy ewes. Genetics Selection Evolution 38:183-200.

Marnet, P.G., and B.C. McKusick. 2001. Regulation of milk ejection and milkability in small ruminants. Livestock Production Science 70:125-133

Martínez, M.E., C. Calderón, R. De la Barra, L.F. De la Fuente, and C. Gonzalo. 2011. Udder morphological traits and milk yield of Chilota and Suffolk down sheep breeds. Chilean Journal of Agricultural Research 71:90-95.

Milerski, M., M. Margetín, A. Čapistrák, D. Apolen, J. Špánik, and M. Oravcová. 2006. Relationships between external and internal udder measurements and the linear scores for udder morphology traits in dairy sheep. Czech Journal of Animal Science 51:383390.

McKusick, B.C., P.G. Marnet, Y.M. Berger, and D.L. Thomas. 2000. Preliminary observations on milk flow and udder morphology traits of East Friesian crossbred dairy ewes. p. 101-116. Proceedings of the $6^{\text {th }}$ Great Lakes Dairy Sheep Symposium, Guelph, Ontario. 2-4 November. Ontario Dairy Sheep Association, Ontario, Canada.

Pérez-Cabal, M.Á., E. Legaz, I. Cervantes, L.F. De la Fuente, R. Martínez, F. Goyache, et al. 2013. Association between body and udder morphological traits and dairy performance in Spanish Assaf sheep. Archiv Tierzucht 56:1-26.

Prpić, Z., B. Mioč, I. Vnučec, V. Držaić, and V. Pavić. 2013. Nongenetic factors of udder morphology traits in Istrian ewes. Mljekarstvo 63:72-80.

Pulina, G., M. Colitti, M. Farinacci, A. Mazzette, G. Canu, C.N. Castro, et al. 2009. The evolution of mammary glands at different stages in Sarda dairy ewes: preliminary results. Italian Journal of Animal Science 8:652-654.
Pulina, G., and A. Nudda. 1996. Technical and physiological aspects of the mechanical milking of sheep. L' Informatore Agrario 52:6974.

Pulina, G., A. Nudda, S.P.G. Rassu, and R. Vallebella. 1996. Measurement of the mammary gland cistern of dairy ewes. L'Informatore Agrario 52:77-78.

Rovai, M., G. Caja, and X. Such. 2008. Evaluation of udder cisterns and effects on milk yield of dairy ewes. Journal of Dairy Science 91:4622-4629.

Rovai, M., D.L. Thomas, Y.M. Berger, and G. Caja. 2004. Udder morphology and effects on milk production and ease of milking in dairy sheep. p. 79-114. Proceedings of the $10^{\text {th }}$ Great Lakes Dairy Sheep Symposium, Wisconsin. 4-6 November. Dairy Sheep Association of North America, Bushnell, Nebraska, USA.

Ruberte, J., A. Carretero, M. Fernández, J. Pons, J.M. Gine, y J. Sautet. 1994. Anatomía de la ubre de la oveja: datos morfológicos necesarios para comprender la producción de leche y el ordeño. Ovis 32:9-16.

Sadeghi, S., S.A. Rafat, M. Ghaderi Zefrei, F. Khaligh, K.H. Rostami, M. Bohlouli, et al. 2013. Factors affecting external and internal mammary morphology traits and assessment of their interrelationships with milk yield in Lori Bakhtiari breed ewes. Livestock Research for Rural Development 25 Article nr 37.

Sagi, R., and M. Morag. 1974. Udder conformation, milk yield and milk fractionation in the dairy ewes. Annales de Zootechnie 23:185-192.

Salama, A.A.K., G. Caja, X. Such, S. Peris, A. Sorensen, and C.H. Knight. 2004. Changes in cisternal udder compartment induced by milking interval in dairy goats milked once or twice daily. Journal of Dairy Science 87:1181-1187.

Salama, A.A.K., X. Such, G. Caja, M. Rovai, R. Casals, E. Albanell, et al. 2003. Effects of once versus twice daily milking throughout lactation on milk yield and milk composition in dairy goats. Journal of Dairy Science 86:1673-1680.

Salaris, S., S. Casu, and A. Carta. 2007. Investigating the relationship between the prion protein locus and udder morphology traits and milk yield in Sardinian sheep. Journal of Animal Science 85:2840-2845

SAS Institute. 2002-2008. Version 9.2. SAS Institute Inc., Cary, North Carolina, USA

Stelwagen, K., C.H. Knight, V.C. Farr, S.G. Davis, C.G. Prosser, and T.B. McFadden. 1996. Continuous versus single drainage of milk from the bovine mammary gland during a 24 hour period. Experimental Physiology 81:141-149.

Tatarczuch, L., C. Philip, and C.S. Lee. 1997. Involution of the sheep mammary gland. Journal of Anatomy 190:405-416.

Tenev, S., and G. Rusev. 1989. Micro and ultrastructure of sheep's udder in breeds with different milk productivity. p. 47-65. Proceedings of the $4^{\text {th }}$ International Symposium on Machine Milking of Small Ruminants, Tel Aviv. 13-19 September. Ministry of Agriculture Israel, Kibbutz Shefayin, Israel.

Ugarte, E., and D. Gabiña. 2004. Recent developments in dairy sheep breeding. Archiv fur Tierzucht 47:10-17. 